\title{
Zastosowanie niskoenergetycznego procesu CMT do lutospawania złączy miedź - stal kwasoodporna w różnych osłonach gazowych
}

\author{
The application of low heat input CMT process \\ in braze welding copper - high-alloy steel joints \\ in various shielding gases
}

\section{Streszczenie}

W artykule przedstawiono problematykę związaną z wykonaniem połączeń lutospawanych miedzi ze stalą kwasoodporną o strukturze austenitycznej. Złącza wykonane zostały niskoenergetyczną metodą CMT oraz MIG łukiem pulsującym na zrobotyzowanym stanowisku przy zastosowaniu osłony gazowej argonu oraz helu. Przedstawiono wyniki badań wizualnych, metalograficznych oraz wytrzymałościowych. Na ich podstawie stwierdzono, iż proces CMT pozwala na wytworzenie złączy o wysokiej jakości, przy dostarczeniu niżej energii cieplnej niż metody klasyczne.

Słowa kluczowe: lutospawanie; złącza różnoimienne; niskoenergetyczne metody spawania; metoda CMT

\section{Abstract}

Within the scope of this article, the issue of creating braze-weld joints of copper and high alloy steel is discussed in detail. The joints were made by using a low-energy CMT welding method and MIG with pulsing arc on a robotized set-up in argon and helium shielding. The results of visual, metallographic and strength test are presented. Based on them, it has been concluded that the CMT process allows for creating high quality joints, while requiring a lower heat input.

Keywords: braze welding; dissimilar joints; low heat input welding methods; CMT method

\section{Wstęp}

Rozwiązania stosowane w nowoczesnym przemyśle motoryzacyjnym czy elektrycznym, wymagają często łączenia ze sobą technologiami spawalniczymi różnoimiennych, najczęściej cienkościennych materiałów konstrukcyjnych. Dążenie do redukcji masy, która przekłada się na większą ekonomiczność czy ekologiczność konstrukcji, wymaga łączenia ze sobą materiałów o znacznych różnicach właściwości fizykochemicznych jak np. temperatura topnienia, rozszerzalność czy przewodność cieplna. Znacznie utrudnia to opracowanie procesu spajania umożliwiającego wykonanie złącza o wymaganej jakości.

Z tego właśnie powodu przedmiotem ciągłych badań są technologie spawalnicze takie jak lutospawanie, które pozwala na łączenie znacznie szerszej gamy materiałów, niż klasyczne spawanie łukowe. Dodatkowo zauważalny jest znaczny rozwój niskoenergetycznych metod łączenia materiałów, które umożliwiają dokładniejszą kontrolę nad ciepłem wprowadzonym do złącza. Do metod tych zaliczyć można: STT firmy Lincoln Electric, CBT firmy Daihen czy przedstawiona w niniejszym artykule metoda CMT - firmy Fronius $[1 \div 4]$.
Metoda spawania CMT ( $\mathrm{z}$ ang. Cold Metal Transfer) jest odmianą procesu GMAW (z ang. Gas Metal Arc Welding), polegającą na spawaniu łukiem zwarciowym z technologią mechanicznego oddzielenia kropli metalu od końca drutu elektrodowego. W klasycznej metodzie spawania GMAW łukiem zwarciowym, kropla przechodzi do jeziorka wskutek wzrostu natężenia prądu zwarcia, który rozrywa przewężenie ciekłego metalu, powodując wprowadzenie dodatkowego ciepła do złącza. W przypadku metody CMT, w momencie wystąpienia zwarcia układ sterujący podawaniem drutu doprowadza do jego cofnięcia, co skutkuje mechanicznym zerwaniem przewężenia. Umożliwia to zmniejszenie energii liniowej spawania, znaczne zmniejszenie ilości występującego rozprysku oraz poprawę estetyki złącza w porównaniu do spawania łukiem zwarciowym $[1,3]$.

Połączenia miedź - stal austenityczna znalazły zastosowania w budowie urządzeń chłodniczych oraz uzwojeń stojanów generatorów dużej mocy. Możliwe jest ich łącznie metodami lutowania twardego z użyciem topników lub w próżni, metodami zgrzewania tarciowego i metodami o dużej

dr inż. Tomasz Wojdat, dr inż. Paweł Kustroń, inż. Filip Skuratowicz, Piotr Michalak, Patrycja Piotrowska - Politechnika Wrocławska.

Autor korespondencyjny/Corresponding author: tomasz.wojdat@pwr.edu.pl 
koncentracji energii (spawanie laserowe lub wiązką elektronów). Dobre rezultaty można uzyskać przy zastosowaniu metody TIG [5] lub niskoenergetycznych metod jak CBT [3]. Znaczącymi problemami w łączeniu stali austenitycznej z miedzą jest ich duża różnica $w$ temperaturze topnienia oraz przewodności cieplnej.

\section{Przebieg i wyniki badań}

Celem badań było określenie przydatności zastosowania metody CMT do lutospawania materiałów różnoimiennych. Otrzymane złącza zostały poddane badaniom nieniszczącym oraz niszczącym, w wyniku których oceniona została ich jakość oraz właściwości wytrzymałościowe. Wyniki badań zostały porównane z wynikami uzyskanymi dla złączy wykonanych klasyczną metodą MIG Puls. Lutospawanie zostało przeprowadzone w osłonie argonu lub helu.

Próby lutospawania przeprowadzono na zrobotyzowanym stanowisku spawalniczym przedstawionym na rysunku 1, składającym się z: inwertorowego źródła prądu TransPuls Synergic 3200 CMT firmy Fronius, podajnika drutu VR 7000CMT 4R/G/W/F++ oraz robota Kawasaki serii BA z zamontowanym uchwytem spawalniczym Robacta Drive CMT PAP W.

Do wykonania złączy próbnych użyto blach miedzianych gat. Cu-ETP w stanie miękkim R220 (wg PN-EN 1625:1999) o wymiarach 2,0 x 250 x 100 oraz blach ze stali kwasoodpornej austenitycznej X5CrNi18-10 (wg PN-EN 10088-2:2014) o wymiarach 2,0 × 250 × 100 i 1,0 × 250 × 100. Skład chemiczny oraz właściwości wybranych materiałów przedstawiono w tablicy I oraz tablicy II.

Jako materiał dodatkowy do lutospawania zastosowano spoiwo na bazie miedzi CuSi3Mn1 o średnicy $1,0 \mathrm{~mm}$. Jego skład chemiczny wraz z własnościami mechanicznymi przedstawiono $w$ tablicy III.

W ramach badań założone zostało wykonanie złączy doczołowych oraz zakładkowych. Złącza doczołowe wykonane zostały z blach o grubości $2 \mathrm{~mm}$, złącza zakładkowe z blach miedzianych o grubości $2 \mathrm{~mm}$ oraz blach ze stali kwasoodpornej o grubości $1 \mathrm{~mm}$. Z racji grubości blach wynoszącej $2 \mathrm{~mm}$, krawędzie blach przeznaczone na złącza doczołowe nie zostały ukosowane. Powierzchnia blach została wyczyszczona włókniną stalową i odtłuszczona. Blachy zostały

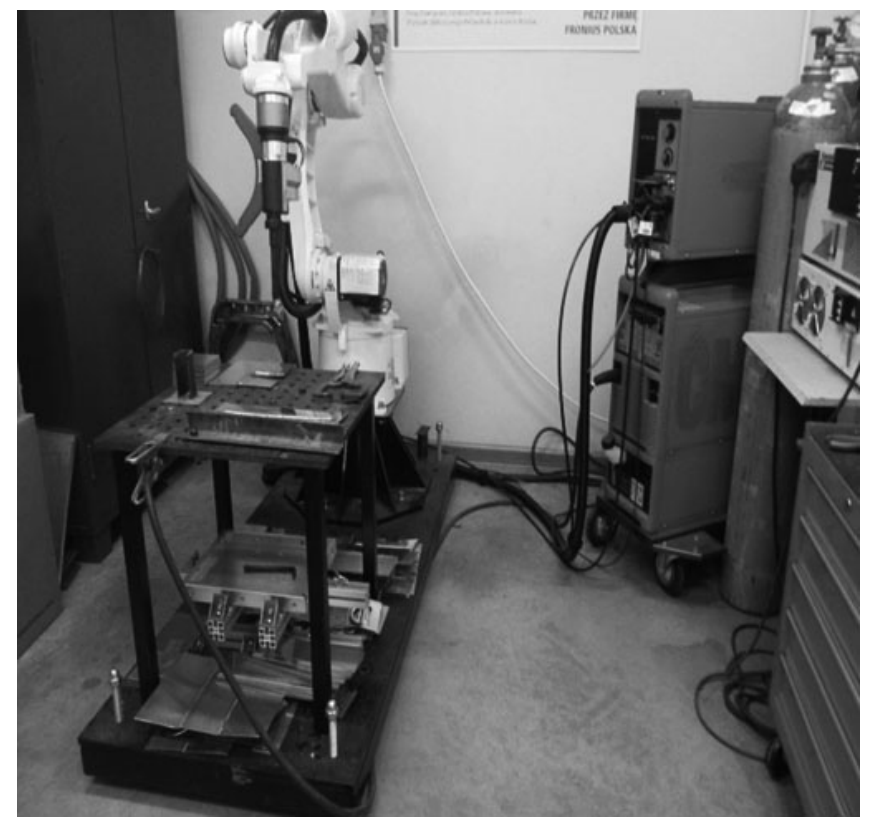

Rys. 1. Stanowisko badawcze do spawania metodą CMT Fig. 1. The test set-up for CMT welding

zamocowane na stole, za pomocą ścisków spawalniczych. Przed właściwym procesem wykonania złączy, wykonane zostały wstępne próby lutospawania. $\mathrm{Na}$ ich podstawie dobrane zostały parametry procesu lutospawania użyte do wykonania złączy do dalszych badań. Drut spawalniczy przesunięty został $2 \mathrm{~mm}$ w kierunku miedzi, w celu wprowadzania większej ilości ciepła do materiału o znacznie większej przewodności cieplnej niż stal austenityczna. Uchwyt spawalniczy pochylono pod kątem $15^{\circ} \mathrm{w}$ kierunku przeciwnym do kierunku lutospawania, długość wolnego wylotu drutu wynosiła $12 \mathrm{~mm}$. Wykonano 4 doczołowe złącza próbne: metodą CMT w osłonie argonu oznaczone jako CMT Ar, metodą CMT w osłonie helu oznaczone jako CMT He oraz metodą MIG łukiem pulsującym w osłonie tych samych gazów oznaczone jako Puls Ar oraz Puls He. Wykonane zostały również 2 zakładkowe złącza próbne, lutospawane metodą CMT w osłonie argonu i helu oznaczone kolejno jako CMT Ar Z oraz CMT He Z. Parametry wykonania złączy próbnych przedstawiono w tablicy IV.

Tablica I. Skład chemiczny i właściwości miedzi Cu-ETP w stanie R220 [6]

Table I. Chemical composition and properties of Cu-ETP in R220 condition [6]

\begin{tabular}{|c|c|c|c|c|c|c|c|c|}
\hline Oznaczenie & \multicolumn{5}{|c|}{ Skład chemiczny [\% wag.] } & \multirow{2}{*}{$\begin{array}{l}\text { Temperatura } \\
\text { topnienia }\left[{ }^{\circ} \mathrm{C}\right]\end{array}$} & \multirow{2}{*}{$\begin{array}{c}\text { Wytrzymałość } \\
\text { na rozciąganie } R_{m} \\
\text { [MPa] }\end{array}$} & \multirow{2}{*}{$\begin{array}{c}\text { Wydłużenie } \\
\text { względne } A_{50}\end{array}$} \\
\hline C-ETP & $\mathrm{Cu}$ & $\mathrm{Bi}$ & 0 & $\mathrm{~Pb}$ & Inne & & & \\
\hline & reszta & 0,0005 & 0,04 & 0,005 & 0,03 & 1085 & $\min .220 \div 260$ & $\min .33$ \\
\hline
\end{tabular}

Tablica II. Skład chemiczny i właściwości stali austenitycznej X5CrNi18-10 [7]

Table II. Chemical composition and properties of austenitic steel X5CrNi1 8-10 [7]

\begin{tabular}{|c|c|c|c|c|c|c|c|c|c|}
\hline Oznaczenie & \multicolumn{6}{|c|}{ Skład chemiczny [\% wag.] } & \multirow{2}{*}{$\begin{array}{l}\text { Temperatura } \\
\text { topnienia }\left[{ }^{\circ} \mathrm{C}\right]\end{array}$} & \multirow{2}{*}{$\begin{array}{c}\text { Wytrzymałość } \\
\text { na rozciąganie } R_{m} \\
\text { [MPa] }\end{array}$} & \multirow{2}{*}{$\begin{array}{c}\text { Wydłużenie } \\
\text { względne } A_{80}[\%]\end{array}$} \\
\hline $\mathrm{X} 5 \mathrm{CrNi1} \mathrm{S}_{1} \mathrm{C}$ & $\mathrm{Fe}$ & C & $\mathrm{Cr}$ & $\mathrm{Ni}$ & $\mathrm{Si}$ & $\mathrm{Mn}$ & & & \\
\hline & reszta & 0,07 & $17,5 \div 19,5$ & $8,0 \div 10,5$ & 1,0 & 2,0 & 1455 & $540 \div 750$ & $\min .45$ \\
\hline
\end{tabular}

Tablica III. Skład chemiczny oraz własności wytrzymałościowe spoiwa CuSi3Mn1 [8]

Table III. Chemical composition and mechanical properties of CuSi3Mn1 filler material [8]

\begin{tabular}{|c|c|c|c|c|c|c|c|c|}
\hline \multirow{2}{*}{ Spoiwo } & \multicolumn{4}{|c|}{ Skład chemiczny } & \multirow{2}{*}{$\begin{array}{c}\text { Temperatura } \\
\left.\text { topnienia [ }{ }^{\circ} \mathrm{C}\right]\end{array}$} & $\begin{array}{c}\text { Umowna granica } \\
\text { plastyczności } \\
\mathbf{R}_{\mathrm{p} 0,2}[\mathrm{MPa}]\end{array}$ & $\begin{array}{c}\text { Wytrzymałość } \\
\text { na rozciąganie } \mathbf{R}_{\mathbf{m}} \\
\text { [MPa] }\end{array}$ & $\begin{array}{c}\text { Wydłużenie } \\
\text { Względne } \mathbf{A}_{5} \text { [\%] }\end{array}$ \\
\hline CuSi3Mn1 & $\mathrm{Cu}$ & $\mathrm{Si}$ & $\mathbf{M n}$ & Inne & 150 & 350 & 40 \\
\hline
\end{tabular}


Na rysunku 2 przedstawiono widok lica oraz grani poszczególnych złączy lutospawanych.

W przypadku CMT Ar, CMT He, Puls Ar, CMT Ar Z oraz CMT He Z uzyskane zostały złącza o zadowalającym wyglądzie zewnętrznym i bez widocznych niezgodności zewnętrznych. Złącze Puls He charakteryzowało się nierównym licem oraz znacznym rozpryskiem, a w obszarze grani zauważony zostałbrak zwilżenia stali austenitycznej o długościl $=35 \mathrm{~mm}$ w połowie długości złącza. Nie zostały zauważone nadtopienia materiału stali austenitycznej.

Tablica IV. Parametry procesu lutospawania

Table IV. Parameters of arc braze welding process

\begin{tabular}{|c|c|c|c|c|}
\hline $\begin{array}{c}\text { Oznacze- } \\
\text { nie próbki }\end{array}$ & $\begin{array}{c}\text { Natężenie } \\
\text { prądu I [A] }\end{array}$ & $\begin{array}{c}\text { Napięciu } \\
\text { łuku U [V] }\end{array}$ & $\begin{array}{c}\text { Prędkość } \\
\text { spawania } \\
\text { [cm/min] }\end{array}$ & $\begin{array}{c}\text { Energia } \\
\text { liniowa } \\
\text { [kJ/cm] }\end{array}$ \\
\hline CMT Ar & 170 & 12 & 55 & 1,78 \\
\hline CMT He & 143 & 16 & 60 & 1,83 \\
\hline Puls Ar & 179 & 20 & 55 & 3,12 \\
\hline Puls He & 146 & 22 & 60 & 2,57 \\
\hline CMT Ar Z & 140 & 12 & 60 & 1,34 \\
\hline CMT He Z & 128 & 16 & 80 & 1,23 \\
\hline
\end{tabular}
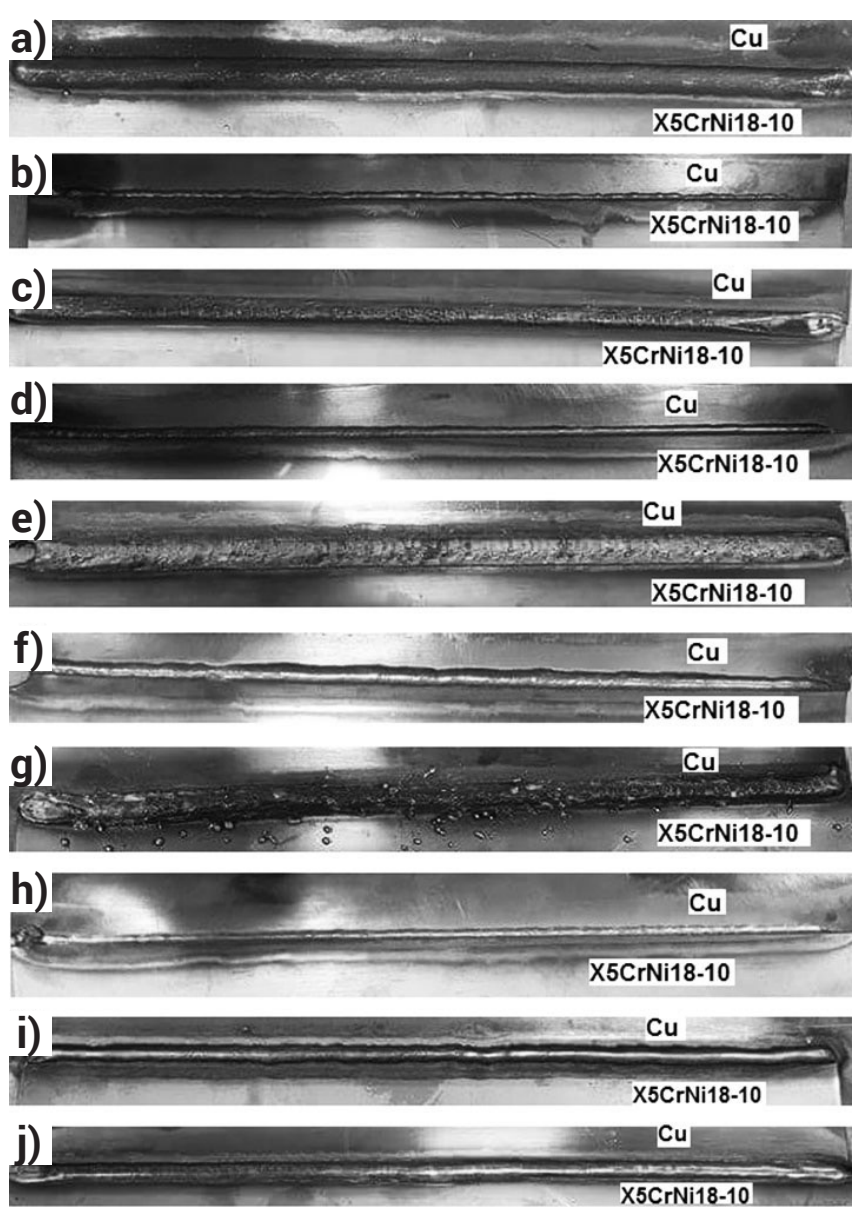

Rys. 2. Lutospawane złącza próbne: a) lico lutospoiny CMT Ar; b) grań lutospoiny CMT Ar; c) lico lutospoiny CMT He; d) grań lutospoiny CMT He; e) lico lutospoiny Puls Ar; f) grań lutospoiny Puls $\mathrm{Ar} ; \mathrm{g})$ lico lutospoiny Pulse $\mathrm{He}$; h) grań lutospoiny Pulse $\mathrm{He}$; i) lico lutospoiny CMT Ar Z; j) lico lutospoiny CMT He Z

Fig. 2. The view of test braze-welded joints: a) face of braze weld CMT Ar; b) root of braze weld CMT Ar; c) face of braze weld CMT He; d) root of braze weld CMT He; e) face of braze weld Puls Ar; f) root of braze weld Puls Ar; g) face of braze weld Puls He; h) root of braze weld Puls He; i) face of braze weld CMT Ar Z; j) face of braze weld CMT He Z

\section{Statyczna próba rozciągania}

Statyczną próbę rozciągania lutospawanych złączy doczołowych wykonano na maszynie wytrzymałościowej Louis Schopper. Prędkość posuwu belki poprzecznej wynosiła 0,2 cm/min, zakres pomiarowy do $10 \mathrm{kN}$. Próbki do badań wytrzymałościowych wykonane zostały zgodnie z PN-EN ISO 4136:2013 [9]. Z każdego złącza pobranych zostało 5 próbek.

Średnia wytrzymałość złączy wykonanych metodami CMT i MIG Puls w osłonie Ar i He przy użyciu spoiwa CuSi3Mn1 wyniosła w zakresie $217 \div 223 \mathrm{MPa}$, w zależności od złącza. Niezależnie od zastosowanej metody czy gazu osłonowego wyniki cechowała niewielka zmienność, różnice między skrajnymi wynikami nie przekraczały $10 \mathrm{MPa}$. Do przełomów dochodziło w obszarze SWC miedzi (rys. 3). Wytrzymałość otrzymanych złączy jest zbliżona do wytrzymałości użytej miedzi (tabl. I).

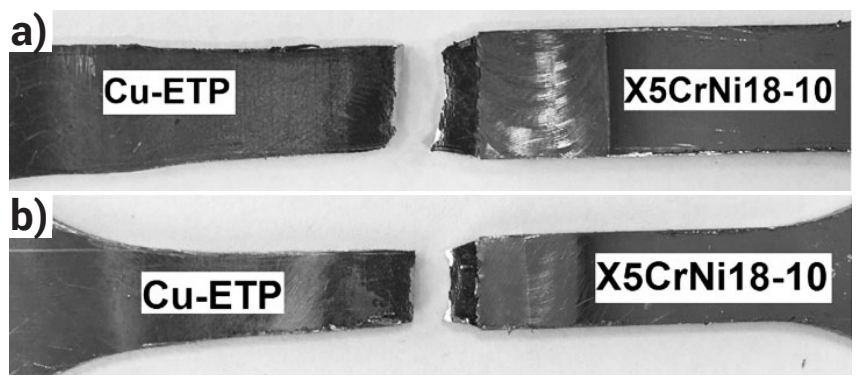

Rys. 3. Przykładowe przełomy złączy lutospawanych po próbie rozciągania: a) przełom w SWC miedzi, CMT He oraz b) przełom w SWC miedzi, CMT Ar

Fig. 3. Exemplary fractures of braze welded joins after tensile test: a) fracture in copper's HAZ, CMT He and b) fracture in copper's HAZ, CMT Ar

\section{Pomiary mikrotwardości}

Pomiary mikrotwardości wykonane zostały na przygotowanych zgładach metalograficznych metodą Vickersa przy obciążeniu 0,1 kG. Do przeprowadzenia pomiarów wykorzystano twardościomierz HVS-1000 firmy Sinowon. Pomiary mikrotwardości przeprowadzono w dwóch liniach: pierwszej w odległości podwojonej przekątnej próbnego odcisku od górnej krawędzi blachy oraz drugiej w tej samej odległości od dolnej krawędzi blachy. Wykonano 13 pomiarów mikrotwardości w każdej linii, pomiary $1 \div 5$ wykonane zostały w miedzi, pomiary $6 \div 10 \mathrm{w}$ obszarze lutospoiny a pomiary $11 \div 13$ w obszarze stali austenitycznej. Wyniki pomiarów zostały uśrednione, celem uzyskania miarodajniejszego rozkładu mikrotwardości na długości próbki. Na rysunku 4 zestawiono wyniki pomiarów mikrotwardości dla każdej z próbek.

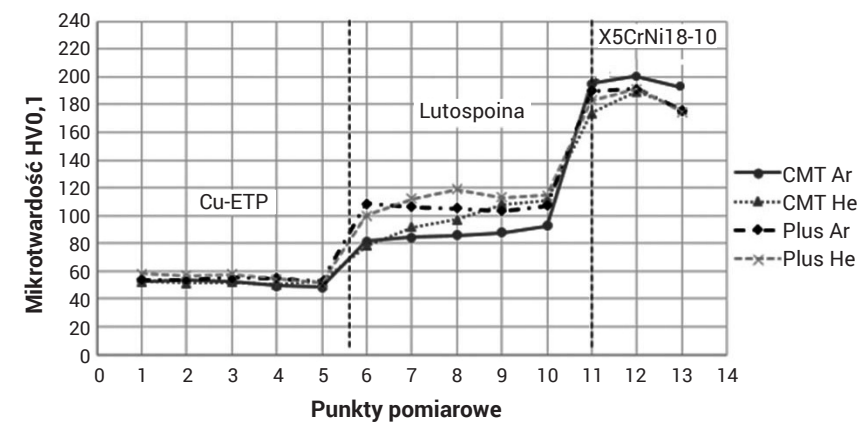

Rys. 4. Zestawienie pomiarów mikrotwardości złączy Cu-ETP - X5CrNi18-10 dla poszczególnych metod lutospawania i gazów osłonowych Fig. 4. Microhardness overview of Cu-ETP - X5CrNi18-10 joints for each braze welding method and shielding gas 
W obszarze lutospoiny zaobserwowane zostały różnice w mikrotwardości między poszczególnymi złączami, dochodzące do $40 \mathrm{HV0,1}$. Ich przyczyną może być niejednorodna struktura lutospoiny, spowodowana wtrąceniami pochodzącymi z nadtopionej stali kwasoodpornej, co skutkuje zwiększeniem mikrotwardości.

\section{Badania metalograficzne}

Z wykonanych złączy wycięte zostały próbki, które zostały zainkludowane w żywicy epoksydowej. Celem wykonania zgładów metalograficznych, próbki zostały szlifowane na papierach ściernych o gradacji od 400 do 2500, a następnie zostały wypolerowane przy użyciu zawiesiny diamentowej o wielkości ziarna $1 \mu \mathrm{m}$. Obserwacje makroskopowe zostały przeprowadzone przy użyciu mikroskopu Olympus SZX7, do przeprowadzenia obserwacji mikroskopowych użyto mikroskopu świetlnego Olympus CK40M oraz skaningowego mikroskopu elektronowego Phenom G2 Pro wyposażonego w detektor BSE.

$\mathrm{Na}$ podstawie badań makrostruktury złączy lutospawanych (rys. 5) stwierdzono, iż najkorzystniejsza makrostruktura występuję $\mathrm{w}$ przypadku zastosowania procesu CMT w osłonie Ar (rys. 5a). Nie doszło do znacznych nadtopień stali austenitycznej, które występują w pozostałych a)
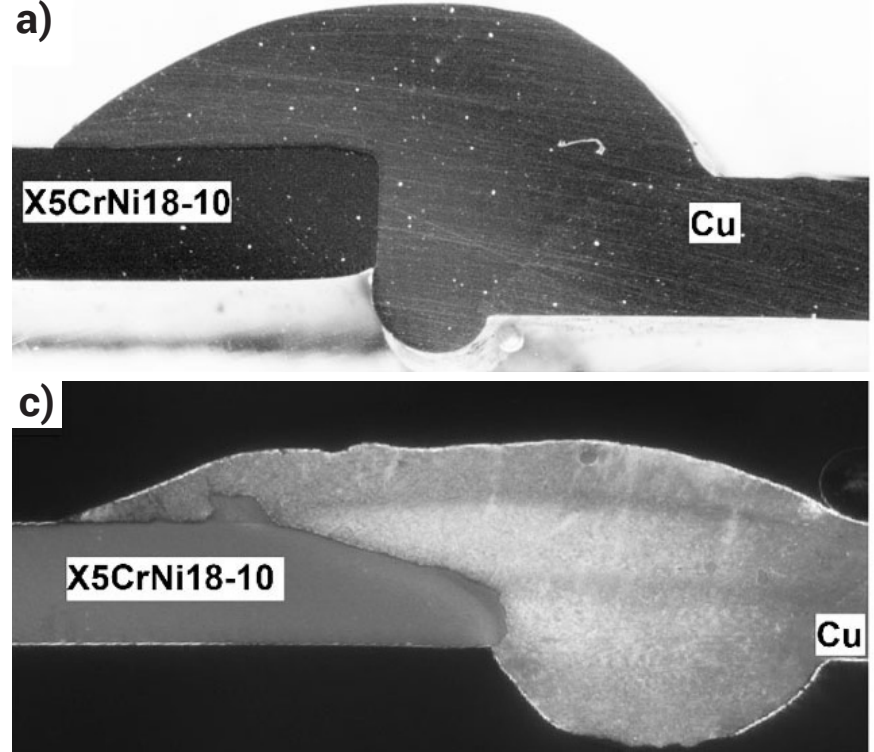

b)

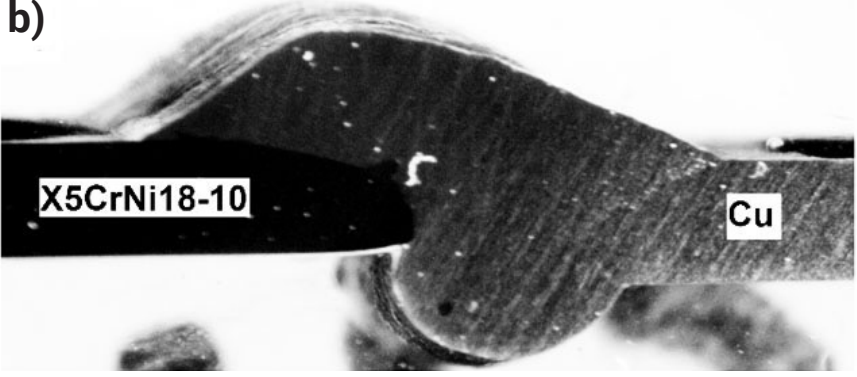

d)

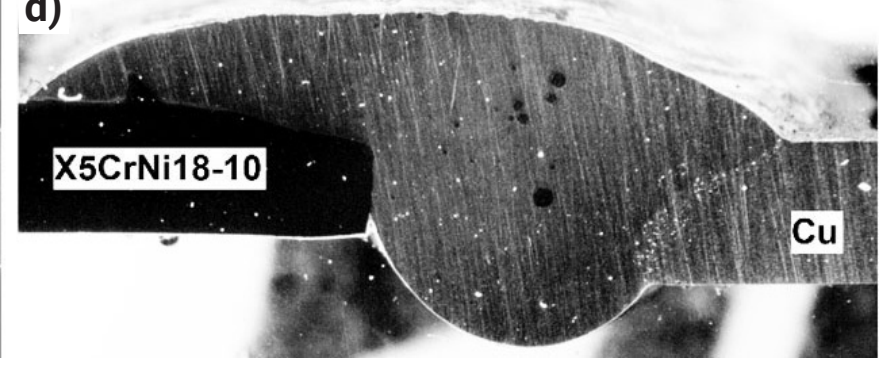

Rys. 5. Makrostruktury złączy lutospawanych: a) CMT Ar; b) CMT He; c) Puls Ar i d) Puls He

Fig. 5. Macrostructure of braze welded joints: a) CMT Ar; b) CMT He; c) Puls Ar and d) Puls He
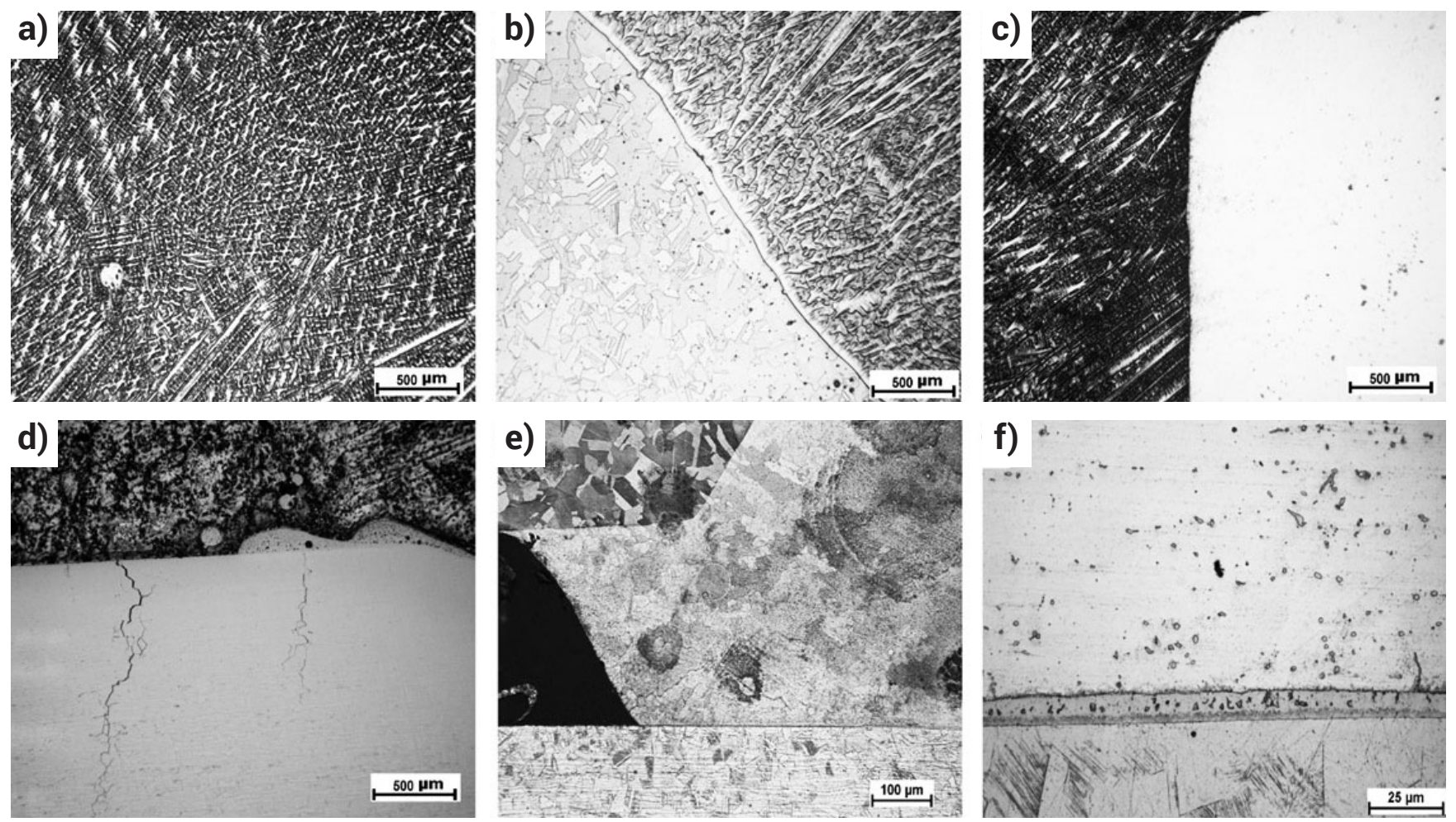

Rys. 6. Mikrostruktury złączy lutospawanych: a) mikrostruktura lutospoiny, CMT Ar; b) strefa wtopienia w materiał miedzi, CMT Ar; c) strefa zwilżenia stali austenitycznej spoiwem, CMT Ar; d) obszary miejscowego stopienia stali austenitycznej z pęknięciami, Puls He; e) widok złącza lutospawanego, CMT He Z; f) obszar zwilżenia stali austenitycznej, CMT Ar Z

Fig. 6. Microstructure of braze welded joints: a) braze weld microstructure, CMT Ar; b) fusion area between copper and braze weld, CMT Ar; c) contact area between austenitic steel and braze weld, CMT Ar; d) areas of local melting of austenitic steel with fractures, Puls He; e) view of braze welded joint, CMT He Z; f) contact area between austenitic steel and braze weld, CMT Ar Z 
próbkach (rys. 5b, 5c i 5d). Ponadto próbka CMT Ar cechuje się najmniejszą szerokością grani i pełnym zwilżeniem powierzchni stali w jej obrębie. W obszarze grani próbki Puls He (rys. 5d) występuje brak zwilżenia stali spoiwem.

W wyniku badań mikroskopowych zbadana została mikrostruktura złączy lutospawanych (rys. 6). W obszarze mikrostruktury próbki CMT Ar (rys. 6c) nie zaobserwowano rozległych stref miejscowego stopienia stali austenitycznej, które zostały zaobserwowane w mikrostrukturach pozostałych złączy doczołowych (rys. 6d). W każdym złączu doczołowym obecne są pęknięcia pod obszarem lutospoiny w głąb stali austenitycznej. W samych lutospoinach nie stwierdzono pęknięć, jedynymi niezgodnościami zaobserwowanymi w ich obszarze są globularne wydzielenia stali austenitycznej, powstałe w wyniku jej nadtopienia (rys. 6d). W mikrostrukturze złączy zakładkowych (rys. 6e, 6f) nie stwierdzono obecności pęknięć w obszarze stali austenitycznej. Jest to najpewniej spowodowane odmienną konstrukcją złączy zakładkowych. W trakcie krzepnięcia lutospoin stal austenityczna odkształcana jest $\mathrm{w}$ kierunku normalnym do powierzchni blachy, w przeciwieństwie do złączy doczołowych, gdzie kierunek odkształceń jest styczny do powierzchni blachy.

Obserwacje za pomocą mikroskopu elektronowego SEM wskazały na międzykrystaliczny charakter pęknięć w stali austenitycznej (rys. 7a, 7b, 7c). Pęknięcia te występowały wyłączenie pod obszarem lutospoiny, nie zostały zaobserwowane w materiale niezwilżonym spoiwem. Charakter tych pęknięć został opisany w [3]. Znaczne naprężenia rozciągające, powstałe wskutek wielokrotnie szybszego odprowadzania ciepła przez blachę miedzianą, umożliwiły wniknięcie lutu do granic ziaren, co doprowadziło do powstania pęknięć na gorąco. Ich brak w obszarze stali niezwilżonej spoiwem, wskazuje na poprawność opisanego powyżej mechanizmu ich powstawania. Na rysunkach $7 \mathrm{~b}$ oraz $7 \mathrm{~d}$ przedstawiających próbkę CMT Ar widoczna jest warstwa dyfuzyjna na powierzchni stali oraz w obszarze pęknięcia. Jej grubość wynosi w granicach $2 \div 3 \mu \mathrm{m}$ zależnie od miejsca pomiaru. W obszarze pozostałych próbek CMT He, Puls Ar i Puls He z racji wystąpienia lokalnych nadtopień (rys. 7c) grubość warstwy dyfuzyjnej cechuje się znaczną zmiennością i nie jest przedmiotem pomiarów.
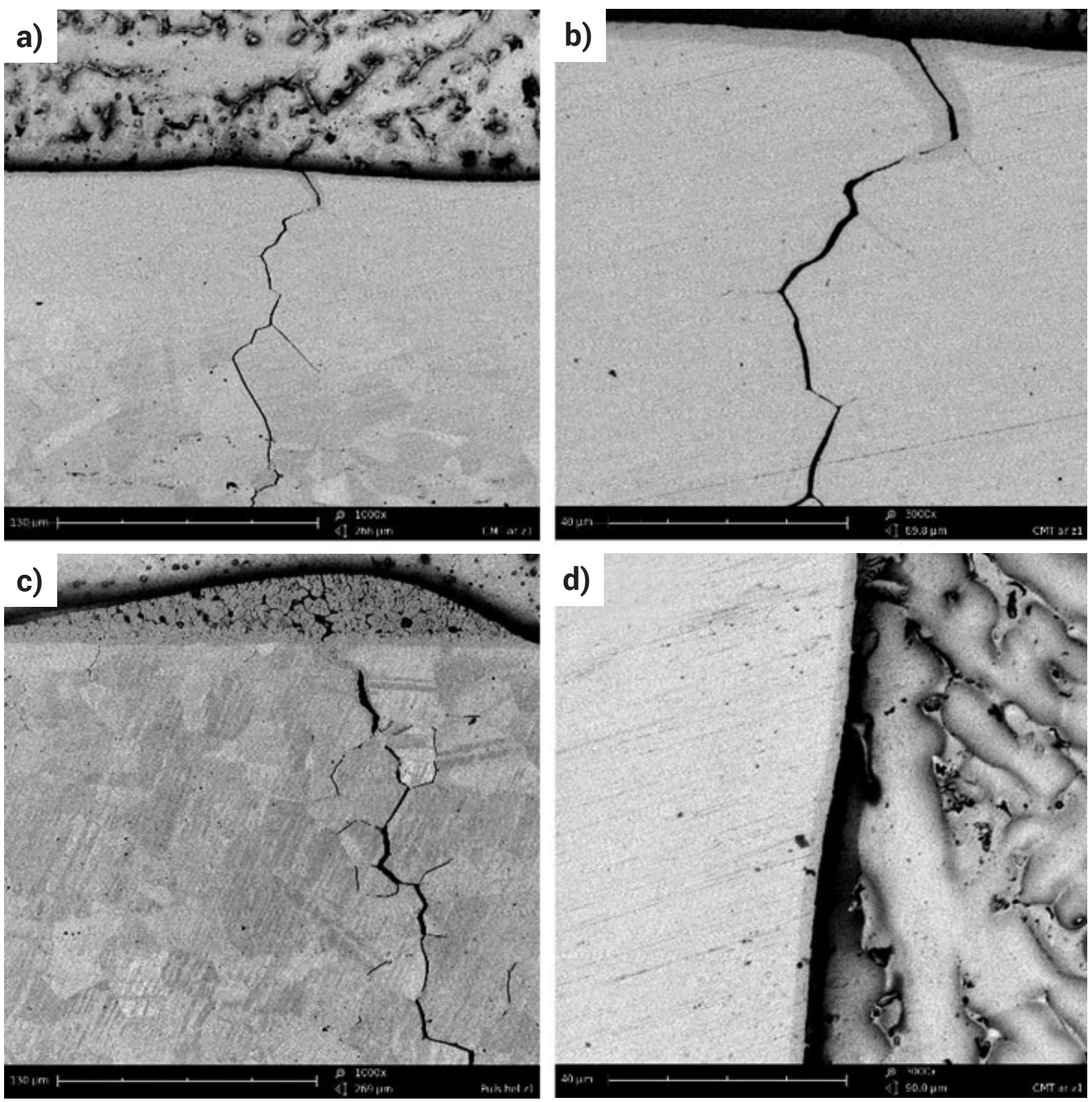

Rys. 7. Mikrostruktura złączy lutospawanych w mikroskopii SEM: a) pęknięcie międzykrystaliczne w obszarze stali austenitycznej, CMT Ar, pow. x1000; b) pęknięcie międzykrystaliczne, CMT Ar, pow. x3000; c) pęknięcie międzykrystaliczne pod strefą nadtopienia, Puls He, pow. x1000; d) obszar warstwy dyfuzyjnej na powierzchni stali austenitycznej, Puls Ar, pow. x3000

Fig. 7. Microstructure of braze welded joints viewed in SEM microscopy: intercrystalline fracture in austenitic steel, CMT Ar, mag. x1000; b) intercrystalline fracture, CMT Ar, mag. $\times 3000 ; c)$ intercrystalline fracture under local partial melting of steel; Puls He, mag. $x 1000$ d) view of diffusion layer in steel, Puls Ar, mag. x3000 


\section{Wnioski}

Na podstawie przeprowadzonych badań sformułowane zostały następujące wnioski:

1. Metoda lutospawania CMT umożliwiła wytworzenie poprawnych złączy doczołowych oraz zakładkowych miedź - stal kwasoodporna przy wprowadzeniu znacznie mniejszej energii cieplnej w stosunku do klasycznej metody MIG łukiem pulsującym oraz przy znacznie mniejszym rozprysku obniżającym walory estetyczne złącza;

2. Złącze doczołowe wykonane metodą CMT w osłonie argonu cechowało się nieznacznym nadtopieniem powierzchni stali austenitycznej, w odróżnieniu od złączy wykonanych metodami MIG łukiem pulsującym w osłonie argonu i helu oraz CMT w osłonie helu, które odznaczały się widocznymi nadtopieniami stali austenitycznej;

3. Obecność pęknięć w obszarze stali austenitycznej złączy doczołowych nie ma wpływu na wytrzymałość statyczną złączy, gdyż każda statyczna próba rozciągania kończyła się przełomem w obszarze miedzi. Jednakże wpływ tych pęknięć na wytrzymałość zmęczeniową badanych złączy jest najpewniej znaczny i zależny od warunków eksploatacyjnych złączy;

4. W obszarze mikrostruktury złączy zakładkowych nie zaobserwowano występowania pęknięć, które obecne są w każdym złączu doczołowym. Jest to spowodowane prawdopodobnie odmiennym rozkładem naprężeń w złączu zakładkowym, które działają normalnie do powierzchni blachy ze stali austenitycznej, co nie powoduje dyfundowania miedzi po granicy ziaren, doprowadzając do pęknięć gorących.

\section{Literatura}

[1] Mirski Z., Pękala P.: Spawanie metodą CMT (Cold Metal Transfer) w porównaniu z klasyczną metodą MAG w przemyśle motoryzacyjnym, Przegląd Spawalnictwa, vol. 88 (2), s.15-20, 2016.

[2] Wojdat T., Kustroń P., Lange A., Łącka I.: Badania właściwości złączy lutospawanych aluminium ze stalą wykonanych przy użyciu spoiw na bazie Al i Zn, Przegląd Spawalnictwa, vol.89 (7), s. 22-25, 2017.

[3] Czupryński A., Kik T., Górka J.: Wykorzystanie niskoenergetycznego procesu CBT do łączenia stali wysokostopowej z miedzią, Przegląd Spawalnictwa, vol. 87 (5), s. 21- 30, 2015

[4] Białucki P., Ambroziak A., Derlukiewicz W., Lange A., Glezman M.: Właściwości złącz lutospawanych aluminium ze stalą, Przegląd Spawalnictwa, vol. 85 (9), s. 40-44, 2015.
[5] Mirski Z., Granat K., Prasałek A.: Spawanie metodą TIG miedzi ze stalą austenityczną, Przegląd Spawalnictwa, vol. 79 (8), s. 58-63, 2007.

[6] PN-EN ISO 1652:1999 Miedź i stopy miedzi - Płyty, blachy, taśmy i krążki ogólnego przeznaczenia.

[7] PN-EN ISO 10088-2:2014-12 Stale odporne na korozję - Część 2: Warunki techniczne dostawy blach cienkich/grubych i taśm ze stali nierdzewnych ogólnego przeznaczenia.

[8] PN-EN 13347:2004 Miedź i stopy miedzi - Pręty i druty do spawania i lutospawania.

[9] PN-EN ISO 4136:2013 Badania niszczące złączy spawanych metali - Próba rozciągania próbek poprzecznych. 